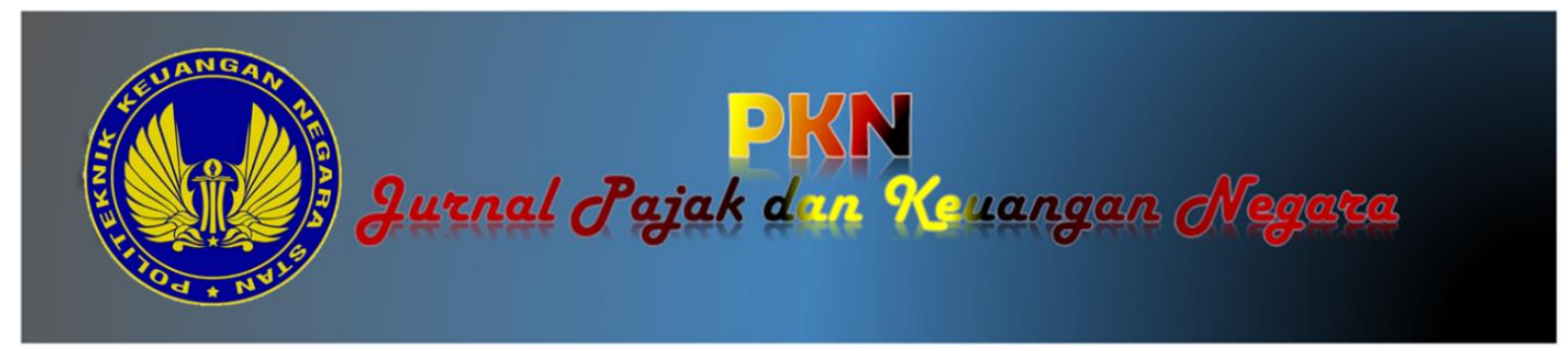

\title{
ANALISIS PERUBAHAN KETENTUAN SUBJEK PAJAK ORANG PRIBADI PADA UNDANG-UNDANG CIPTA KERJA TERHADAP PAJAK PENGHASILAN ORANG PRIBADI DAN MOBILITAS SUMBER DAYA MANUSIA
}

\author{
Yustika Dewi Prastiwi, \\ Politeknik Keuangan Negara STAN \\ Rd. Tatan Jaka Tresnajaya, \\ Politeknik Keuangan Negara STAN \\ Alamat Korespondensi: yustika02.yt@gmail.com
}

\author{
INFORMASI ARTIKEL \\ Diterima Pertama \\ [30 07 2021] \\ Dinyatakan Diterima \\ [15 09 2021] \\ KATA KUNCI: \\ Undang-Undang Cipta Kerja, Subjek Pajak Orang \\ Pribadi, Pajak Penghasilan, Mobilitas Sumber Daya \\ Manusia \\ KEYWORDS: \\ Job Creation Act, Individual Tax Subject, Income Tax, \\ Mobility of Human Resources \\ KLASIFIKASI JEL: \\ $\mathrm{H} 210$
}

\section{ABSTRACT}

Job Creation Act contains new provisions related to individual tax subjects that are quite different from the Income Tax Law. Those provisions include criteria for individual tax subjects, tax exemptions for some foreign incomes, and the application of special tax schemes. Those provisions can affect the income tax base, shifting the tax system into a territorial system, create injustice issues from different tax treatments, and transform the mobility of human resources due to tax facilities in special tax schemes. This study analyzes those potential impacts using the library method. Stated that the Job Creation Law does not change the sentence of Article 4 Paragraph (1) of the Income Tax Law so that Indonesia still tends a worldwide system. The special tax schemes do not have a significant effect on the mobility of human resources because the mobility response not only depends on tax policies but also on other factors. Then, the new tax exemptions and the special tax schemes are not applied for free but accompanied by conditions to invest in Indonesia and transfer knowledge. Thus, the potential reduction in the tax base and tax injustice issues must be addressed wisely and oriented to the prospect of future benefits.

\section{ABSTRAK}

Reformasi pajak dalam Undang-Undang Cipta Kerja memuat ketentuan baru terkait subjek pajak orang pribadi yang cukup berbeda dengan Undang-Undang Pajak Penghasilan, seperti kriteria subjek pajak orang pribadi, pengecualian pajak beberapa penghasilan luar negeri, serta penerapan skema pajak khusus bagi warga negara asing yang telah menjadi subjek pajak dalam negeri. Ketentuan baru tersebut dapat berdampak pada basis pajak penghasilan, pergeseran sistem pajak menuju sistem teritorial, penyimpangan prinsip keadilan akibat perbedaan perlakuan pajak, serta mobilitas sumber daya manusia akibat keringanan pajak yang ditawarkan dalam skema pajak khusus. Penelitian ini menganalisis potensi dampak tersebut menggunakan 
metode kepustakaan dengan teknik dokumentasi. Faktanya, Undang-Undang Cipta Kerja tidak mengubah narasi Pasal 4 Ayat (1) Undang-Undang Pajak Penghasilan sehingga sistem pajak Indonesia masih memiliki kecenderungan terhadap sistem worldwide. Keringanan pajak dalam skema pajak khusus juga tidak berpengaruh signifikan terhadap mobilitas sumber daya manusia, terutama tenaga kerja asing, karena respon mobilitas tidak hanya bergantung pada kebijakan pajak. Kemudian, pengecualian pajak beberapa penghasilan luar negeri dan penerapan skema pajak khusus juga tidak dilakukan secara cuma-cuma, melainkan diiringi syarat untuk menempatkan investasi di Indonesia dan melakukan alih pengetahuan. Dengan demikian, potensi penurunan basis pajak dan penyimpangan prinsip keadilan harus disikapi dengan bijaksana dan berorientasi pada prospek manfaat di masa mendatang.

\section{PENDAHULUAN}

Undang-Undang Nomor 11 Tahun 2020 tentang Cipta Kerja yang disahkan pada 2 November 2020 memuat beberapa ketentuan baru terkait pajak penghasilan. Dalam ketentuan baru tersebut, ketentuan yang melingkupi subjek pajak orang pribadi memiliki perbedaan yang cukup signifikan dari ketentuan sebelumnya yang diatur dengan Undang-Undang Nomor 36 Tahun 2008 tentang Perubahan Keempat atas UndangUndang Nomor 7 Tahun 1983 tentang Pajak Penghasilan. Perbedaan tersebut dapat terlihat dalam ketentuan mengenai kriteria subjek pajak orang pribadi, pengecualian pajak beberapa penghasilan luar negeri, serta penerapan skema pajak khusus bagi warga negara asing yang telah menjadi subjek pajak dalam negeri. Terkait ketentuan mengenai kriteria subjek pajak orang pribadi, Mantan Direktur Jenderal Pajak, Robert Pakpahan, mengatakan perubahan ketentuan subjek pajak tersebut dilakukan untuk memberi kepastian pemajakan bagi wajib pajak orang pribadi dalam negeri maupun luar negeri (Setiawan, 2019).

Ketentuan Undang-Undang Cipta Kerja lain yang berbeda dengan Undang-Undang Pajak Penghasilan adalah penerapan pengecualian pajak terhadap beberapa penghasilan luar negeri serta skema pajak khusus yang mengatur bahwa warga negara asing (WNA) yang telah menjadi subjek pajak dalam negeri (SPDN) akan dikenai pajak penghasilan hanya atas penghasilan yang diterima atau diperoleh dari Indonesia. Hal tersebut terlihat menggeser sistem pajak worldwide yang selama ini dianut Indonesia. Selain itu, adanya penerapan skema pajak khusus tersebut juga akan menyebabkan perbedaan beban pajak bagi subjek pajak dalam negeri (SPDN), yaitu antara warga negara asing (WNA) dan warga negara Indonesia (WNI). Padahal, pemungutan dan pembagian beban pajak sejatinya tidak lepas dari unsur keadilan (Suparnyo, 2012).

Adanya perbedaan beban pajak tersebut juga disinyalir dapat berpengaruh pada mobilitas tenaga kerja. Hal tersebut didasarkan pada penelitian Claus et al. (2011) yang menyebutkan bahwa terdapat hubungan positif antara pengenaan pajak terhadap tingkat migrasi tenaga kerja suatu negara.

Salah satu bukti bahwa pajak dapat memengaruhi mobilitas tenaga kerja terjadi di Denmark. Pada tahun 1992, Denmark memberlakukan skema pajak khusus bagi pekerja asing berpenghasilan tinggi. Melalui skema pajak khusus tersebut, pekerja asing berpenghasilan tinggi di Denmark akan dikenai pajak dengan tarif khusus yang hampir dua kali lebih rendah dari tarif pajak umum. Hasil penelitian yang dilakukan Kleven et al. (2014) menyatakan bahwa keringanan pajak yang ditawarkan Denmark kepada pekerja asing melalui skema pajak khusus tersebut menimbulkan peningkatan signifikan terhadap jumlah tenaga kerja asing yang beremigrasi ke Denmark. Temuan penelitian tersebut menunjukkan bahwa keringanan pajak dapat menjadi salah satu pertimbangan dalam keputusan migrasi tenaga kerja asing.

Kebijakan Denmark

untuk memberlakukan skema khusus terhadap pekerja asing hampir sama dengan langkah yang diambil Indonesia melalui Undang-Undang Cipta Kerja. Jika skema pajak khusus di Denmark memberikan tarif pajak yang lebih rendah kepada pekerja asing, skema pajak khusus di Indonesia memberikan pengecualian pajak atas penghasilan luar negeri yang diterima oleh pekerja asing. Meskipun terdapat perbedaan mekanisme, sejatinya kedua skema pajak khusus tersebut menawarkan pengenaan pajak yang lebih ringan kepada pekerja asing dibandingkan dengan pengenaan pajak kepada warga negara yang bersangkutan.

Berdasarkan hal tersebut, adanya keringanan beban pajak yang ditawarkan Indonesia melalui skema khusus bagi SPDN WNA dalam Undang-Undang Cipta Kerja dapat berpotensi memengaruhi mobilitas sumber daya manusia, terutama tenaga kerja asing dengan meningkatkan ketertarikan tenaga kerja asing terhadap Indonesia. Kemudian, perbedaanperbedaan lain antara Undang-Undang Cipta Kerja dan Undang-Undang Pajak Penghasilan juga berpotensi memunculkan dampak-dampak lain. Dengan demikian, penulis akan menganalisis pengaruh perubahan ketentuan subjek pajak orang pribadi dalam Undang-Undang Cipta Kerja terhadap pajak penghasilan orang pribadi serta potensi dampak yang timbul dari perubahan 
ketentuan tersebut terhadap mobilitas sumber daya manusia.

\section{KERANGKA TEORI}

\subsection{Asas Pengenaan Pajak}

Pada umumnya, asas pengenaan pajak dibedakan menjadi asas domisili (residence principle) dan asas sumber (source / territoriality principle). Asas domisili dikenal juga dengan sebutan worldwide principle. Menurut asas ini, orang pribadi yang merupakan penduduk atau berdomisili di suatu negara akan dikenakan pajak atas penghasilan yang ia terima atau peroleh. Dalam hal ini, asal penghasilan tidak dipermasalahkan sehingga pajak akan dikenakan baik atas penghasilan yang diperoleh dari dalam negeri maupun luar negeri (Direktorat Jenderal Pajak, n.d.).

Selanjutnya, asas sumber dalam pengenaan pajak dikenal juga dengan sebutan territoriality principle. Berdasarkan asas ini, pajak dikenakan atas penghasilan yang diterima atau diperoleh orang pribadi apabila penghasilan tersebut bersumber dari negara tersebut. Dengan demikian, dalam asas ini, status subjek pajak orang pribadi tidak dipersoalkan karena yang menjadi dasar pemajakan adalah objek pajak yang timbul atau berasal dari negara tersebut (Direktorat Jenderal Pajak, n.d.).

Meskipun demikian, dalam praktiknya, jarang ditemukan negara yang menganut satu sistem pajak secara utuh dan menyeluruh (Darussalam et al., 2018). Mullins (2006) menyatakan bahwa negara yang menganut sistem worldwide juga dapat memiliki beberapa elemen dari sistem teritorial, demikian sebaliknya.

Adanya perpaduan dari dua sistem tersebut menyebabkan munculnya sistem pajak hybrid, yaitu sistem pajak yang memiliki elemen worldwide principle sekaligus territoriality principle. Sistem sistem pajak hybrid yang memiliki kecenderungan terhadap worldwide principle disebut sistem pajak hybrid worldwide. Contohnya adalah pengenaan pajak atas semua penghasilan yang diterima atau diperoleh wajib pajak dalam negeri (WPDN) dengan beberapa pengecualian, seperti pengecualian terhadap dividen yang bersumber dari luar negeri. Sementara itu, sistem pajak hybrid yang memiliki kecenderungan terhadap territorial principle atau disebut sistem pajak hybrid territorial. Contohnya adalah penerapan sistem pajak teritorial dengan basis remittance, serta penerapan sistem pajak teritorial terbatas untuk untuk penghasilan aktif yang diterima oleh wajib pajak (Darussalam et al., 2018).

\subsection{Keadilan Pajak}

Dikutip dalam Kadir (2016), salah satu prinsip keadilan pajak dibahas oleh Adam Smith dalam bukunya yang berjudul An Inquiry into the Nature and Causes of the Wealth of Nations. Dalam buku tersebut dinyatakan bahwa dalam memungut pajak, pemungut pajak harus membuat dan mengikuti peraturan yang didasarkan pada rasa keadilan dengan memenuhi prinsip certainty, equality, convenience, dan economic (efisiensi). Equality atau kesamaan dalam sistem perpajakan juga lazim disebut dengan non-discrimination. Hal tersebut memiliki arti bahwa seseorang, baik orang asing maupun warga negara Indonesia, yang berada dalam keadaan yang sama akan diperlakukan sama dan dikenakan pajak yang sama besarnya. Dengan demikian, beban pajak yang ditanggung oleh masing-masing subjek pajak seimbang dengan kemampuan atau penghasilannya.

Selanjutnya, menurut Kadir (2016), keadilan pajak terutama keadilan dalam pembagian beban pajak dibagi ke dalam beberapa pendekatan, yaitu prinsip kemanfaatan (benefit principle) dan prinsip kemampuan membayar (ability-to-pay principle). Menurut benefit principle, pengenaan pajak seharusnya seimbang dengan manfaat (benefit) yang diperoleh wajib pajak dari jasa-jasa publik yang diberikan oleh pemerintah (Kadir, 2016). Sementara itu, abilityto-pay principle memiliki arti bahwa dalam mencukupi kebutuhan perekonomian melalui pajak, setiap wajib pajak dibebani pajak sesuai dengan kemampuannya (Wicaksono, 2014).

Mengacu pada ability-to-pay principle tersebut, Wicaksono (2014) membagi keadilan pajak menjadi dua kelompok besar, yaitu keadilan horizontal dan keadilan vertikal. Dalam keadilan horizontal, orang-orang yang mempunyai kemampuan yang sama harus membayar pajak dalam jumlah yang sama pula. Sementara itu, dalam keadilan vertikal diatur bahwa orang-orang yang mempunyai kemampuan yang berbeda harus membayar pajak dengan jumlah yang berbeda pula.

\subsection{Definisi dan Faktor Mobilitas}

Menurut Badan Pusat Statistik (2019), mobilitas penduduk adalah pergerakan (movement) penduduk dari daerah satu menuju daerah lain dalam periode waktu tertentu. Mobilitas penduduk terdiri dari dua macam, yaitu mobilitas horizontal dan mobilitas vertikal. Mobilitas horizontal kemudian dibagi lagi menjadi dua, yaitu mobilitas permanen dan mobilitas nonpermanen. Mobilitas permanen atau migrasi adalah kondisi ketika seseorang melakukan mobilitas dengan niat untuk menetap di daerah 
tujuan. Sementara itu, mobilitas nonpermanen adalah mobilitas yang dilakukan oleh seseorang tanpa niat untuk menetap di daerah tujuan.

Proses migrasi (mobilitas permanen) sendiri memiliki beragam konsep dan teori, salah satunya adalah teori migrasi menurut Everett $\mathrm{S}$. Lee. Lee (1966) mengungkapkan bahwa setiap daerah memiliki beberapa faktor negatif, faktor positif, dan faktor netral. Faktor-faktor tersebut kemudian membentuk interaksi dengan faktorfaktor di daerah lain sehingga menimbulkan trade off atau benturan kepentingan bagi tiap penduduk dan memicu timbulnya niat melakukan migrasi.

Menurut Lee (1966), ketika tempat asal memiliki lebih banyak faktor negatif daripada faktor positif, seseorang akan terdorong untuk meninggalkan daerah tersebut. Sementara itu, ketika tempat tujuan memiliki lebih banyak faktor positif daripada faktor negatif, hal tersebut akan menjadi daya tarik yang dapat mengundang seseorang untuk pindah ke daerah tersebut. Meskipun demikian, keputusan seseorang dalam melakukan migrasi tidak hanya ditentukan oleh faktor-faktor eksternal, tetapi juga dipengaruhi oleh faktor-faktor personal atau pribadi. Seringkali, faktor personal ini menjadi faktor yang sangat menentukan pengambilan keputusan migrasi karena pada dasarnya penilaian positif dan negatif suatu daerah tergantung pada persepsi individu itu sendiri.

\section{METODE PENELITIAN}

Metode yang digunakan untuk memperoleh dan menganalisis data dalam penelitian ini adalah metode penelitian kepustakaan. Data dalam penelitian ini akan dikumpulkan dengan menggunakan metode dokumentasi sehingga data yang digunakan merupakan data sekunder.

Selanjutnya, data akan dianalisis menggunakan teknik analisis data model Miles and Huberman. Sugiyono (2013) mengemukakan bahwa dalam model Miles and Huberman, analisis kualitatif dilakukan melalui beberapa aktivitas, yaitu reduksi data, data display, dan gambaran kesimpulan. Reduksi data mencakup kegiatan untuk merangkum, memilih dan memfokuskan hal-hal yang penting, serta pentransformasian data sehingga didapatkan temuan yang menjadi fokus penelitian. Data yang telah direduksi tersebut kemudian disajikan dan disusun ke dalam pola hubungan sehingga meningkatkan pemahaman dan memudahkan penentuan langkah selanjutnya (data display). Pada akhirnya, datadata yang diteliti tersebut akan digunakan untuk menarik kesimpulan (conclusion drawing).

\section{HASIL PENELITIAN}

Perbedaan ketentuan antara UndangUndang Cipta Kerja dan Undang-Undang Pajak Penghasilan, beserta dampak atau pengaruh yang menyertainya akan dibahas ke dalam beberapa bagian sebagai berikut.

\subsection{Perbedaan Kriteria Subjek Pajak Orang Pribadi}

Pada dasarnya, orang pribadi dapat digolongkan menjadi subjek pajak dalam negeri (SPDN) atau subjek pajak luar negeri (SPLN) berdasarkan kriteria yang dimilikinya. Penentuan subjek pajak bagi orang pribadi tersebut penting karena berkaitan dengan pemenuhan kewajiban pelaporan pajak. Namun, kriteria subjek pajak bagi orang pribadi yang diatur dalam Undang-Undang Cipta Kerja mengalami sedikit perbedaan dari aturan lama yang terdapat dalam Undang-Undang Pajak Penghasilan. Adapun perbandingan ketentuan mengenai kriteria subjek pajak orang pribadi dalam negeri dapat dilihat dalam Tabel 1 berikut.

Tabel 1 Kriteria Subjek Pajak Orang Pribadi Dalam Negeri

\begin{tabular}{|c|c|}
\hline \multicolumn{2}{|c|}{ Perubahan Pasal 2 Ayat (3) huruf a } \\
\hline $\begin{array}{r}\text { Undang-Unc } \\
\text { Pengh }\end{array}$ & Undang-Undang Cipta Kerja \\
\hline $\begin{array}{l}\text { Termasuk subjek pajak } \\
\text { dalam negeri adalah } \\
\text { orang pribadi yang } \\
\text { bertempat tinggal di } \\
\text { Indonesia, orang } \\
\text { pribadi yang berada di } \\
\text { Indonesia lebih dari } \\
183 \text { hari dalam jangka } \\
\text { waktu } 12 \text { bulan, atau } \\
\text { orang pribadi yang } \\
\text { dalam suatu tahun } \\
\text { pajak berada di } \\
\text { Indonesia dan } \\
\text { mempunyai niat untuk } \\
\text { bertempat tinggal di } \\
\text { Indonesia. }\end{array}$ & $\begin{array}{l}\text { Termasuk subjek pajak dalam } \\
\text { negeri adalah orang pribadi, } \\
\text { baik yang merupakan warga } \\
\text { negara Indonesia (WNI) } \\
\text { maupun warga negara asing } \\
\text { (WNA) yang: } \\
\text { 1. Bertempat tinggal di } \\
\text { Indonesia; } \\
\text { 2. Berada di Indonesia } \\
\text { lebih dari 183 hari } \\
\text { dalam jangka waktu } 12 \\
\text { bulan; atau suatu tahun } \\
\text { 3. Dalam suatu di } \\
\text { pajak berada dan } \\
\text { Indonesia nan diat untuk } \\
\text { mempunyai nial dia } \\
\text { bertempat tinggal di } \\
\text { Indonesia }\end{array}$ \\
\hline
\end{tabular}

Diolah dari: Undang-Undang Republik Indonesia

Nomor 36 Tahun 2008 dan Undang-Undang

Republik Indonesia Nomor 11 Tahun 2020

Berdasarkan Tabel 1 tersebut, UndangUndang Pajak Penghasilan tidak memberikan penjelasan lebih lanjut mengenai definisi orang pribadi. Meskipun demikian, dalam praktiknya, orang pribadi diartikan sebagai manusia secara perseorangan dan bukan badan usaha ataupun badan hukum (Setiyawan, 2019). Hal tersebut berbeda dengan ketentuan dalam Undang-Undang Cipta Kerja karena Undang-Undang Cipta Kerja memuat definisi orang pribadi secara lebih jelas. 
Dalam Undang-Undang Cipta Kerja, dinyatakan bahwa yang dimaksud dengan orang pribadi mencakup warga negara Indonesia (WNI) maupun warga negara asing (WNA).

Namun, terlepas dari kejelasan definisi terkait orang pribadi, Undang-Undang Cipta Kerja dan Undang-Undang Pajak Penghasilan masih menitikberatkan penggunaan asas domisili dalam menentukan status subjek pajak dalam negeri. Penggunaan asas domisili ini ditunjukkan dengan dipertahankannya unsur keberadaan (existence) sebagai syarat utama dalam kriteria subjek pajak dalam negeri (SPDN) tersebut.

Selanjutnya, perbedaan kriteria subjek pajak orang pribadi dalam Undang-Undang Pajak Penghasilan dan Undang-Undang Cipta Kerja juga dapat ditemukan pada ketentuan mengenai kriteria subjek pajak orang pribadi luar negeri dalam Tabel 2 berikut.

\section{Tabel 2 Kriteria Subjek Pajak Orang Pribadi Luar}

$$
\text { Negeri }
$$

\section{Perubahan Pasal 2 Ayat (4)}

\begin{tabular}{|c|c|}
\hline \multicolumn{2}{|r|}{ Perubahan Pasal 2 Ayat (4) } \\
\hline $\begin{array}{l}\text { Undang- } \\
\text { Undang } \\
\text { Pajak } \\
\text { Penghasilan }\end{array}$ & $\begin{array}{l}\text { Termasuk subjek pajak luar negeri } \\
\text { adalah orang pribadi yang tidak } \\
\text { bertempat tinggal di Indonesia, orang } \\
\text { pribadi yang berada di Indonesia } \\
\text { tidak lebih dari } 183 \text { hari dalam jangka } \\
\text { waktu } 12 \text { bulan, yang: } \\
\text { a. menjalankan usaha atau } \\
\text { kegiatan melalui bentuk usaha } \\
\text { tetap (BUT) di Indonesia; atau } \\
\text { dapat menerima atau } \\
\text { memperoleh penghasilan dari } \\
\text { Indonesia tidak dari } \\
\text { menjalankan usaha atau } \\
\text { melakukan kegiatan melalui } \\
\text { bentuk usaha tetap (BUT) di } \\
\text { Indonesia }\end{array}$ \\
\hline $\begin{array}{c}\text { Undang- } \\
\text { Undang } \\
\text { Cipta Kerja }\end{array}$ & $\begin{array}{l}\text { Termasuk subjek pajak luar negeri } \\
\text { adalah: } \\
\text { a. orang pribadi yang tidak } \\
\text { bertempat tinggal di Indonesia; } \\
\text { b. warga negara asing (WNA) yang } \\
\text { berada di Indonesia tidak lebih } \\
\text { dari } 183 \text { hari dalam jangka } \\
\text { waktu } 12 \text { bulan; } \\
\text { c. warga negara Indonesia yang } \\
\text { berada di luar Indonesia lebih } \\
\text { dari } 183 \text { hari dalam jangka } \\
\text { waktu } 12 \text { bulan serta memenuhi } \\
\text { persyaratan: } \\
\text { 1. tempat tinggal; } \\
\text { 2. pusat kegiatan utama; } \\
\text { 3. tempat menjalankan } \\
\text { kebiasaan; } \\
\text { 4. status subjek pajak; } \\
\text { 5. persyaratan tantan } \\
\text { yang menjalankan usaha atau }\end{array}$ \\
\hline
\end{tabular}

\begin{tabular}{|l|l|}
\hline & melakukan kegiatan melalui bentuk \\
usaha tetap (BUT) di Indonesia atau \\
yang dapat menerima atau \\
memperoleh penghasilan dari \\
Indonesia tidak dari menjalankan \\
usaha atau melakukan kegiatan \\
melalui bentuk usaha tetap (BUT) di \\
Indonesia.
\end{tabular}

Diolah dari: Undang-Undang Republik Indonesia Nomor 36 Tahun 2008 dan Undang-Undang Republik Indonesia Nomor 11 Tahun 2020

Berdasarkan perbandingan pada Tabel 2, terlihat pula bahwa Undang-Undang Pajak Penghasilan tidak memberikan penjelasan lebih lanjut mengenai definisi orang pribadi. Sementara, Undang-Undang Cipta Kerja memberikan penjabaran dengan menggunakan istilah-istilah kewarganegaraan (seperti WNI dan WNA) dan menyantumkan syarat berjenjang terkait tiebreaker rule bagi WNI untuk mengidentifikasi status subjek pajaknya.

Sebelum Undang-Undang Cipta Kerja disahkan, definisi mengenai orang pribadi juga tidak disebutkan dengan tegas pada UndangUndang Nomor 16 Tahun 2009 tentang Penetapan Peraturan Pemerintah Pengganti Undang-Undang Nomor 5 Tahun 2008 Tentang Perubahan Keempat atas Undang-Undang Nomor 6 Tahun 1983 Tentang Ketentuan Umum dan Tata Cara Perpajakan Menjadi Undang-Undang (UndangUndang KUP). Pasal 2 Ayat 1 Undang-Undang KUP hanya menyebutkan bahwa untuk menjadi wajib pajak, seseorang harus memenuhi persyaratan subjektif dan objektif. Syarat objektif adalah kondisi ketika orang pribadi telah menerima atau memperoleh penghasilan atau diwajibkan untuk melakukan pemotongan/pemungutan sesuai dengan ketentuan Undang-Undang Pajak Penghasilan. Sementara itu, kewajiban subjektif bagi orang pribadi dimulai saat orang pribadi tersebut dilahirkan, berada, atau berniat untuk bertempat tinggal di Indonesia dan berakhir saat meninggal dunia atau meninggalkan Indonesia untuk selama-lamanya. Konsep "meninggalkan Indonesia untuk selama-lamanya" tersebut harus dikaitkan dengan hal-hal yang nyata pada saat orang pribadi tersebut meninggalkan Indonesia.

Meskipun telah diberikan penjelasan mengenai kondisi berakhirnya kewajiban subjektif bagi orang pribadi, penjelasan tersebut masih meninggalkan ambiguitas. Perlu dilakukan kajian lebih lanjut untuk mengetahui definisi "meninggalkan Indonesia untuk selama-lamanya" ini diartikan melepas status kewarganegaraan atau mengikuti prinsip keberadaan. Berkaitan dengan hal tersebut, seringkali ditemukan kerancuan mengenai perlakuan pajak penghasilan bagi WNI 
yang memenuhi syarat sebagai subjek pajak luar negeri. Masyarakat merasa belum yakin dapat menjadi subjek pajak luar negeri (SPLN) karena merasa terikat dengan status kewarganegaraan sebagai WNI. Dalam praktiknya, kebanyakan WNI tersebut masih melaporkan Surat Pemberitahuan (SPT) ke Indonesia (Setiyawan, 2019).

Dengan demikian, adanya revisi ketentuan dalam Undang-Undang Cipta Kerja ini dapat membantu memperjelas pemahaman masyarakat. Penjabaran kriteria subjek pajak orang pribadi dengan menggunakan istilah-istilah kewarganegaraan (seperti WNI dan WNA), serta penyantuman tie-breaker rule menegaskan bahwa aspek perpajakan Indonesia pada dasarnya tidak melihat dari sisi WNI atau WNA, tetapi melihat kriteria-kriteria orang tersebut dapat dimasukkan dalam kategori subjek pajak dalam negeri (SPDN) atau subjek pajak luar negeri (SPLN).

\subsection{Keterkaitan Perubahan Ketentuan Subjek \\ Pajak Orang Pribadi terhadap Asas Pengenaan Pajak \\ Selain memperjelas kriteria subjek pajak} orang pribadi, Undang-Undang Cipta Kerja juga menetapkan beberapa ketentuan baru terhadap subjek pajak orang pribadi, antara lain pemberian skema pajak khusus dan penghapusan pajak penghasilan atas beberapa jenis penghasilan. Penjelasan masing-masing ketentuan tersebut adalah sebagai berikut.

4.2.1 Skema Khusus Pengenaan Pajak terhadap WNA yang Telah Menjadi SPDN

Sebelumnya, pada Undang-Undang Pajak Penghasilan, diatur bahwa atas penghasilan yang diterima atau diperoleh wajib pajak baik yang berasal dari Indonesia maupun dari luar Indonesia akan dikenai pajak penghasilan sesuai dengan ketentuan peraturan perundang-undangan pajak penghasilan. Kini, pada Undang-Undang Cipta Kerja, terdapat skema khusus yang mengatur bahwa WNA yang telah menjadi SPDN dikenai pajak penghasilan hanya atas penghasilan yang diterima atau diperoleh dari Indonesia, termasuk pula penghasilan yang diterima atau diperoleh sehubungan dengan pekerjaan/jasa/kegiatan di Indonesia dengan nama dan dalam bentuk apapun yang dibayarkan di luar Indonesia.

Namun, skema khusus ini tidak berlaku bagi WNA yang memanfaatkan Perjanjian Penghindaran Pajak Berganda (P3B) antara Pemerintah Indonesia dan pemerintah negara mitra atau yurisdiksi mitra P3B tempat WNA tersebut memperoleh penghasilan dari luar Indonesia. Dengan demikian, jika WNA yang telah menjadi SPDN tersebut memiliki penghasilan yang bersumber dari Indonesia dan dari luar negeri, ia dapat memilih untuk dikenai pajak penghasilan hanya atas penghasilan yang diterima/diperoleh di Indonesia atau memanfaatkan P3B antara Pemerintah Indonesia dengan yurisdiksi negara mitra tempat ia memperoleh penghasilan luar negeri. Jika WNA tersebut memilih untuk menggunakan skema khusus maka otoritas pajak Indonesia hanya akan mengenakan pajak terhadap penghasilan yang berasal dari Indonesia. Sementara itu, jika WNA tersebut memilih untuk memanfaatkan P3B maka otoritas pajak Indonesia akan mengenakan pajak terhadap seluruh penghasilan baik yang berasal dari Indonesia maupun luar negeri. Dengan demikian, pajak yang telah dibayarkan di luar negeri atas penghasilan luar negeri tersebut (dengan tarif sesuai P3B), dapat diperhitungkan sebagai kredit pajak penghasilan di Indonesia sesuai dengan ketentuan peraturan perpajakan.

Lebih lanjut, jika dilihat dari ketentuan skema khusus yang diperuntukkan bagi SPDN WNA dengan keahlian tertentu serta kewajiban untuk melakukan alih pengetahuan, hal ini mengindikasikan bahwa pemberlakuan skema khusus ini tidak semata-mata untuk meringankan pajak WNA yang baru menjadi SPDN, tetapi juga diharapkan dapat menjadi stimulus terjadinya transfer keahlian dan keterampilan yang dapat menjadi investasi bagi peningkatan kualitas modal manusia di masa mendatang.

4.2.2 Penghapusan Pajak Penghasilan atas Beberapa Penghasilan yang Diterima WPDN Undang-Undang Cipta Kerja menambahkan beberapa penghasilan yang dikecualikan dari objek pajak penghasilan, yaitu dividen yang berasal dari dalam negeri atau luar negeri yang diterima oleh wajib pajak dalam negeri (WPDN) baik oleh orang pribadi maupun badan, serta penghasilan lain yang berasal dari luar negeri. Penghasilan lain yang berasal dari luar negeri tersebut meliputi penghasilan luar negeri yang diterima/diperoleh WPDN melalui Bentuk Usaha Tetap (BUT) luar negeri dan/atau penghasilan luar negeri yang diterima/diperoleh WPDN tidak melalui BUT luar negeri dengan syarat berasal dari usaha aktif di luar negeri dan bukan penghasilan dari perusahaan yang dimiliki di luar negeri. Perbandingan ketentuan dalam UndangUndang Cipta Kerja dan Undang-Undang Pajak Penghasilan dapat dilihat dalam Tabel 3 berikut.

Tabel 3 Ketentuan Pajak atas Dividen dan Penghasilan Luar Negeri

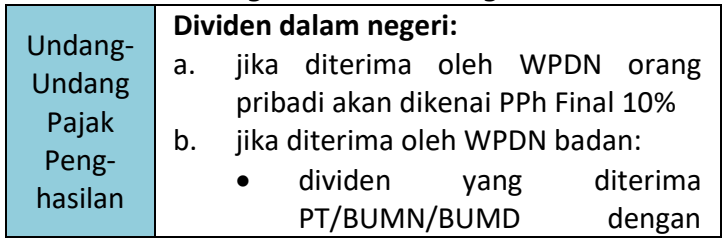




\begin{tabular}{|c|c|}
\hline & $\begin{array}{l}\text { kepemilikan paling rendah 25\% } \\
\text { dikecualikan dari objek PPh } \\
\text { dividen yang diterima koperasi } \\
\text { bukan objek PPh } \\
\text { selain dua ketentuan di atas, } \\
\text { akan dikenai PPh dengan tarif } \\
\text { normal } \\
\text { Dividen dan penghasilan lain dari luar } \\
\text { negeri: Dikenakan tarif PPh Pasal 17 dan } \\
\text { dikreditkan dengan PPh yang dikenakan } \\
\text { di luar negeri }\end{array}$ \\
\hline $\begin{array}{c}\text { Undang- } \\
\text { Undang } \\
\text { Cipta } \\
\text { Kerja }\end{array}$ & $\begin{array}{l}\text { Dividen dalam negeri: } \\
\text { a. jika diterima WPDN orang pribadi, } \\
\text { tidak akan dikenakan PPh sepanjang } \\
\text { diinvestasikan di wilayah NKRI } \\
\text { dalam waktu tertentu } \\
\text { b. dividen yang diterima WPDN badan } \\
\text { dengan kepemilikan saham } \\
\text { berapapun tidak dikenai PPh } \\
\text { Dividen dan penghasilan lain dari luar } \\
\text { negeri: Dikecualikan dari objek PPh } \\
\text { dengan syarat harus diinvestasikan atau } \\
\text { digunakan untuk mendukung kegiatan } \\
\text { usaha lainnya di wilayah NKRI dalam } \\
\text { jangka waktu tertentu. Bagi dividen luar } \\
\text { negeri dan penghasilan lain luar negeri } \\
\text { melalui BUT, batasan minimal investasi } \\
\text { adalah } 30 \% \text { dari laba setelah pajak. }\end{array}$ \\
\hline
\end{tabular}

Diolah dari: Undang-Undang Republik Indonesia

Nomor 36 Tahun 2008 dan Undang-Undang

Republik Indonesia Nomor 11 Tahun 2020

Pengecualian dividen dari objek PPh membuat sistem pemajakan dividen di Indonesia, yang tadinya classical system, berubah menjadi one tier system. Pada classical system, sebagaimana diterapkan dalam Undang-Undang Pajak Penghasilan, penghasilan yang diperoleh perusahaan akan dikenakan pajak sebanyak dua kali, yaitu pada tingkat perusahaan dan pada tingkat pemegang saham saat dibagikan sebagai dividen. Sementara itu, pada one tier system, pajak atas penghasilan perusahaan hanya akan dikenakan satu kali di tingkat perusahaan dan tidak akan dikenai pajak lagi saat diterima sebagai dividen oleh pemegang saham (Marantika, 2021).

Lebih lanjut, pengecualian pengenaan pajak terhadap dividen ini diiringi syarat untuk menginvestasikan dividen tersebut ke wilayah NKRI. Dengan demikian, perubahan sistem pemajakan dividen ini diharapkan tidak hanya dapat menghindari pemajakan berganda ekonomis atas laba perusahaan, tetapi juga dapat memberi ruang pendanaan untuk menambah investasi.

\subsubsection{Implikasi Perubahan Ketentuan Subjek Pajak Orang Pribadi terhadap Asas Pengenaan Pajak \\ Penerapan ketentuan baru, seperti skema} pajak khusus dan pengecualian pajak terhadap penghasilan luar negeri ini mengindikasikan bahwa asas pengenaan pajak Indonesia mulai mengadopsi beberapa unsur dari asas sumber (territoriality principle), yaitu mengenakan pajak hanya atas penghasilan yang bersumber dari Indonesia, meskipun hanya pada lini tertentu.

Meskipun demikian, perlu diingat kembali bahwa tidak ada satu negara pun yang menerapkan sistem pajak secara murni, baik worldwide system maupun territorial system (Fleming et al., 2008). Hal senada juga diungkapkan Mullins (2006) bahwa negara yang menganut worldwide system pun dimungkinkan untuk memiliki beberapa elemen dari territorial system atau sebaliknya sehingga memunculkan sistem pajak hybrid.

Berkaitan dengan hal tersebut, jika diteliti lebih lanjut, skema khusus yang mengenakan pajak penghasilan hanya atas penghasilan bersumber dari Indonesia merupakan opsi yang diperuntukkan bagi SPDN WNA dengan kriteria tertentu. Skema tersebut menjadi tidak berlaku apabila SPDN WNA memilih untuk memanfaatkan ketentuan P3B antara Indonesia dan negara mitra atas penghasilan luar negeri yang diperolehnya. Pengecualian pajak terhadap beberapa penghasilan luar negeri pun diberlakukan secara bersyarat sepanjang penghasilan tersebut diinvestasikan di Indonesia. Hal-hal tersebut dapat mengindikasikan bahwa sebenarnya pengenaan pajak di Indonesia masih memiliki kecenderungan pada worldwide system.

Kecenderungan tersebut juga diperkuat dengan Undang-Undang Cipta Kerja yang tidak mengubah narasi Pasal 4 ayat 1 yang menyatakan bahwa objek pajak adalah penghasilan yang diterima atau diperoleh wajib pajak baik berasal dari Indonesia maupun dari luar Indonesia, dengan nama dan dalam bentuk apapun. Lebih lanjut, Darussalam et al. (2018) menyatakan bahwa pengecualian pengenaan pajak atas dividen luar negeri dan/atau laba dari BUT yang berada di luar negeri termasuk salah satu bentuk sistem pajak hybrid worldwide. Dengan demikian, berdasarkan hal-hal tersebut, asas pengenaan pajak di Indonesia dapat dikategorikan ke dalam sistem pajak hybrid worldwide.

\subsection{Dampak Perubahan Ketentuan Subjek Pajak}

Orang Pribadi terhadap Pajak Penghasilan

Adanya ketentuan-ketentuan baru yang melingkupi subjek pajak orang pribadi, seperti pengecualian dividen (baik dividen dalam negeri 
maupun luar negeri) serta penghasilan luar negeri (baik melalui BUT maupun tidak melalui BUT) dari objek pajak penghasilan dapat mengurangi basis pajak penghasilan (Saptono \& Ayudia, 2021). Adanya penurunan basis pajak penghasilan ini tidak hanya terjadi pada subjek pajak dalam negeri (SPDN), tetapi juga pada subjek pajak luar negeri (SPLN).

Penurunan basis pajak penghasilan pada SPDN antara lain disebabkan oleh berkurangnya penerimaan PPh Final atas dividen yang diterima wajib pajak orang pribadi akibat penghapusan PPh atas dividen dari dalam negeri, berkurangnya potensi penerimaan PPh atas penghasilan luar negeri milik wajib pajak orang pribadi akibat pengecualian penghasilan tertentu (termasuk dividen) luar negeri dari objek pajak, serta berkurangnya potensi penerimaan PPh atas penghasilan luar negeri milik SPDN WNA akibat adanya skema khusus bagi SPDN WNA.

Sementara itu, penurunan basis pajak penghasilan pada SPLN disebabkan UndangUndang Cipta Kerja mengatur adanya peluang penurunan tarif pemotongan PPh Pasal 26 sebesar $20 \%$ dari jumlah bruto atas penghasilan berupa bunga, termasuk premium, diskonto, dan imbalan sehubungan dengan jaminan pengembalian utang yang dibayarkan kepada wajib pajak luar negeri. Ketentuan tersebut kemudian ditindaklanjuti dengan Peraturan Pemerintah Republik Indonesia Nomor 9 Tahun 2021 tentang Perlakuan Perpajakan untuk Mendukung Kemudahan Berusaha, yang menyatakan bahwa tarif pemotongan PPh Pasal 26 atas penghasilan bunga obligasi (termasuk syariah) yang diterima/diperoleh WPLN selain BUT menjadi sebesar $10 \%$ atau sesuai P3B.

\subsection{Pengaruh Perubahan Ketentuan Subjek Pajak Orang Pribadi terhadap Prinsip Keadilan Pajak}

Skema pajak khusus yang memungkinkan SPDN WNA dikenai pajak penghasilan hanya atas penghasilan yang diterima atau diperoleh dari Indonesia menimbulkan perbedaan perlakuan dengan pemajakan yang dikenakan terhadap SPDN WNI. Hal tersebut dapat menimbulkan perbedaan tarif pajak efektif bagi pihak penerima manfaat skema dan pihak yang bukan penerima manfaat skema. Dengan asumsi bahwa pihak-pihak memiliki kondisi yang sama (dalam hal ini, jumlah dan jenis penghasilan, serta penghasilan tidak kena pajak (PTKP) wajib pajak diasumsikan sama) maka perbedaan tarif pajak efektif dapat digambarkan dalam Tabel 4 berikut.

\begin{tabular}{|c|c|c|c|c|}
\hline \multicolumn{5}{|c|}{ Tabel 4 Perbandingan Tarif Pajak Efektif } \\
\hline & \multicolumn{2}{|c|}{ UU PPh } & \multicolumn{2}{|c|}{ UU Cipta Kerja } \\
\hline & SPDN WNI & SPDN WNA & SPDN WNI & SPDN WNA \\
\hline $\begin{array}{l}\text { Penghasilan } \\
\text { DN }\end{array}$ & 600.000 .000 & 600.000 .000 & 600.000 .000 & 600.000 .000 \\
\hline $\begin{array}{l}\text { Penghasilan } \\
\text { LN* }\end{array}$ & 100.000 .000 & 100.000 .000 & 100.000 .000 & 100.000 .000 \\
\hline PTKP & 54.000 .000 & 54.000 .000 & 54.000 .000 & 54.000 .000 \\
\hline PKP & 646.000 .000 & 646.000 .000 & 646.000 .000 & 546.000 .000 \\
\hline \multicolumn{5}{|c|}{ Tarif PPh OP: } \\
\hline $5 \%$ & 2.500 .000 & 2.500 .000 & 2.500 .000 & 2.500 .000 \\
\hline $15 \%$ & 30.000 .000 & 30.000 .000 & 30.000 .000 & 30.000 .000 \\
\hline $25 \%$ & 62.500 .000 & 62.500 .000 & 62.500 .000 & 62.500 .000 \\
\hline \multirow[t]{2}{*}{$30 \%$} & 43.800 .000 & 43.800 .000 & 43.800 .000 & 13.800 .000 \\
\hline & 138.800 .000 & 138.800 .000 & 138.800 .000 & 108.800 .000 \\
\hline $\begin{array}{l}\text { Tarif pajak } \\
\text { efektif }\end{array}$ & $21,49 \%$ & $21,49 \%$ & $21,49 \%$ & $19,93 \%$ \\
\hline $\begin{array}{l}\text { Tarif pajak } \\
\text { marjinal }\end{array}$ & $30 \%$ & $30 \%$ & $30 \%$ & $30 \%$ \\
\hline
\end{tabular}

*dalam kondisi penghasilan luar negeri tidak diinvestasikan ke Indonesia

Sumber: diolah penulis

Berdasarkan perbandingan pada Tabel 4 tersebut, dapat dilihat bahwa SPDN WNA yang memanfaatkan skema khusus pada UndangUndang Cipta Kerja akan memiliki tarif pajak efektif lebih rendah daripada SPDN WNI. Hal ini dikarenakan, menurut skema, penghasilan luar negeri yang diterima SPDN WNA tersebut dikecualikan dari pengenaan pajak di Indonesia.

Sejalan dengan ilustrasi dalam Tabel 4, Saptono dan Ayudia (2021) mengungkapkan bahwa fasilitas pajak bagi orang asing yang menjadi subjek pajak dalam negeri dapat menimbulkan diskriminasi terbalik. Diskriminasi terbalik adalah kondisi ketika perlakuan pajak WNA lebih baik daripada WNI padahal keduanya berdomisili di Indonesia dan memiliki kondisi ekonomi yang sama atau melakukan transaksi yang identik. Dalam hukum pajak, larangan terhadap diskriminasi tersebut terdapat dalam Pasal 24 Perjanjian Penghindaran Pajak Berganda, terutama yang mengadopsi OECD Model.

Meskipun demikian, perlu digarisbawahi bahwa selain mengatur adanya skema khusus bagi SPDN WNA, Undang-Undang Cipta Kerja juga mengatur adanya pengecualian pajak penghasilan terhadap dividen luar negeri serta penghasilan luar negeri yang diterima/diperoleh SPDN sepanjang diinvestasikan di Indonesia. Apabila penghasilan luar negeri milik SPDN WNI pada ilustrasi Tabel 4 diinvestasikan di Indonesia, maka penghasilan tersebut dapat dikecualikan dari pengenaan pajak sehingga tarif pajak efektif SPDN WNI akan sama 
PAJAK PENGHASILAN ORANG PRIBADI DAN MOBILITAS

SUMBER DAYA MANUSIA

Yustika Dewi Prastiwi, Rd. Tatan Jaka Tresnajaya

dengan SPDN WNA yang menerima manfaat skema khusus.

Menyikapi fenomena tersebut, pada dasarnya salah satu kriteria terpenting untuk menyebarkan beban pajak penghasilan di antara wajib pajak orang pribadi adalah proposisi bahwa tanggung jawab tersebut harus dialokasikan atas dasar kesejahteraan ekonomi komparatif. Namun, tentu saja akan ada banyak kesempatan ketika prinsip tersebut harus tunduk pada pertimbangan lain (Fleming et al., 2008).

Darussalam et al. (2019) juga menyatakan bahwa secara normatif, kebijakan pajak seharusnya dapat dijalankan berdasarkan prinsip best policy, yang di dalamnya sudah pasti mengandung unsur keadilan dan netralitas. Namun, pada praktiknya, kondisi ideal untuk mencapai best policy sulit diterapkan di lapangan karena kebijakan pajak seringkali bersinggungan dengan kepentingan-kepentingan ekonomi yang lain. Meskipun demikian, pemungutan pajak dilakukan dengan tujuan dan manfaat yang lebih besar, yaitu bagi sebesar-besarnya kemakmuran rakyat.

Bercermin dari hal tersebut, dapat kita tinjau kembali bahwa skema khusus bagi SPDN WNA tidak diberlakukan secara cuma-cuma, tetapi disertai dengan syarat bagi WNA tersebut untuk melakukan alih pengetahuan. Demikian halnya dengan pengecualian dividen dan penghasilan dari objek pajak yang disertai syarat untuk menginvestasikan penghasilan tersebut di Indonesia dalam kurun waktu tertentu.

Syarat-syarat tersebut mengindikasikan bahwa dibalik kebijakan pajak yang diberlakukan, terdapat niat pemerintah untuk meningkatkan investasi modal dan sumber daya manusia dalam negeri dalam rangka membawa Indonesia menuju perekonomian yang lebih baik. Hal tersebut sesuai dengan prinsip untuk mengarahkan kebijakan pajak sedekat mungkin pada tujuan dan manfaat utama, yaitu kemakmuran rakyat. Dengan demikian, adanya perbedaan tarif pajak efektif yang tidak sesuai dengan prinsip keadilan khususnya ability-to-pay principle hendaknya dapat disikapi dengan bijaksana sesuai dengan prospek yang dapat diperoleh di masa mendatang.

\subsection{Dampak Perubahan Ketentuan Subjek Pajak Orang Pribadi terhadap Mobilitas Sumber Daya Manusia}

Reformasi perpajakan dalam UndangUndang Cipta Kerja, pada dasarnya, bertujuan untuk meningkatkan daya tarik iklim investasi, kepatuhan pajak sukarela, serta kepastian hukum bagi kemudahan usaha. Sesuai hal tersebut, berbagai keringanan pajak yang ditawarkan diharapkan dapat menarik investasi, baik investasi modal fisik maupun modal manusia, ke Indonesia.

Strategi pemerintah dalam menarik lebih banyak investasi modal fisik dan modal manusia tersebut sejalan dengan kebijakan Masyarakat Ekonomi ASEAN (MEA). The AEC Blueprint 2025, yang memberikan arahan luas melalui langkahlangkah strategis untuk MEA dari tahun 2016 hingga 2025, menyatakan bahwa ASEAN sedang memasuki fase pembangunan ekonomi yang ditandai dengan peran penting dari mobilitas keterampilan dalam rangka meningkatkan rantai nilai global (Asian Development Bank, 2019). Adanya kesamaan haluan bagi negara-negara ASEAN melalui The AEC Blueprint 2025 juga dapat menimbulkan kompetisi antarnegara. Oleh karena itu, untuk mengefektifkan strategi yang diambil, Indonesia harus memperhitungkan daya saingnya dengan negara-negara lain di rumpun ASEAN.

Di antara negara-negara di kawasan ASEAN, rupanya Malaysia dan Thailand menjadi negara ASEAN yang masuk dalam kategori negara yang menampung migran internasional terbesar menurut United Nations (n.d.). Fluktuasi jumlah migran internasional di Malaysia dan Thailand adalah sebagai berikut.

Tabel 5 Jumlah Migran Internasional di Malaysia dan Thailand

\begin{tabular}{|c|c|c|c|c|c|c|}
\hline \multirow{2}{*}{ Negara } & \multicolumn{6}{|c|}{ Jumlah migran internasional dalam jutaan jiwa } \\
\cline { 2 - 7 } & $\mathbf{1 9 9 5}$ & $\mathbf{2 0 0 0}$ & $\mathbf{2 0 0 5}$ & $\mathbf{2 0 1 0}$ & $\mathbf{2 0 1 5}$ & $\mathbf{2 0 1 9}$ \\
\hline Malaysia & 0,9 & 1,5 & 1,9 & 2,4 & 3,3 & 3,4 \\
\hline Thailand & 0,8 & 1,3 & 2,2 & 3,2 & 3,5 & 3,6 \\
\hline
\end{tabular}

Sumber : United Nations

Keberhasilan Malaysia dan Thailand menjadi salah satu dari dua puluh negara yang menampung migran paling banyak dapat dijadikan sebagai tolok ukur untuk menilai keunggulan dan kelemahan yang dimiliki Indonesia dalam menarik migran potensial di masa depan. Berbekal dengan reformasi perpajakan sebagai salah satu stimulus dalam menarik investasi sumber daya manusia, kita dapat membandingkan terlebih dahulu kebijakan pajak, khususnya pajak terhadap orang pribadi, yang berlaku di masing-masing negara tersebut. Perbandingan kebijakan pajak, sebagaimana dimuat dalam Deloitte Southeast Asia Ltd (2020), secara umum sebagai berikut:

1. Basis:

a. Indonesia

Residen dikenai pajak atas pendapatan kotornya dengan worldwide principle, dikurangi dengan pengurangan yang diperbolehkan dan pendapatan yang tidak dapat dikenai pajak. Nonresiden dikenakan pajak hanya atas sumber pendapatan dari Indonesia. 
PAJAK PENGHASILAN ORANG PRIBADI DAN MOBILITAS

SUMBER DAYA MANUSIA

Yustika Dewi Prastiwi, Rd. Tatan Jaka Tresnajaya

b. Malaysia

Individu dikenakan pajak atas penghasilan yang diperoleh dari Malaysia. Pendapatan dari luar negeri dikecualikan di Malaysia.

c. Thailand

Residen dan nonresiden Thailand dikenai pajak atas pendapatan mereka yang berasal dari Thailand. Residen Thailand dikenai pajak atas sumber pendapatan asing hanya jika pendapatan tersebut dibawa ke Thailand pada tahun yang sama (repatriasi di tahun-tahun berikutnya dibebaskan dari pajak penghasilan pribadi).

2. Tarif

a. Indonesia

Pajak penghasilan dikenakan dengan tarif progresif hingga 30 persen untuk wajib pajak dalam negeri.

b. Malaysia

Pajak penghasilan dikenakan dengan tarif progresif hingga 30 persen untuk residen. Individu yang tidak memenuhi persyaratan sebagai residen dikenai pajak tetap sebesar 30 persen.

c. Thailand

Penghasilan yang dapat dinilai dikenai pajak dengan tarif progresif, hingga tingkat maksimum 35 persen dari penghasilan di atas THB 5 juta. Karyawan asing dari IBC mungkin berhak atas tarif pajak pendapatan tetap sebesar 15 persen atau pembebasan pajak dalam kasus tertentu. Dividen dan bunga dikenakan pajak pada sumbernya masingmasing dengan tarif 10 dan 15 persen.

Berdasarkan perbandingan beberapa kebijakan pajak umum pada masing-masing negara tersebut, terlihat bahwa pengecualian penghasilan luar negeri bagi pemajakan SPDN WNA yang diatur dalam Undang-Undang Cipta Kerja menjadi tidak istimewa lagi karena negara lain juga memiliki ketentuan basis pajak yang hampir mirip.

Meskipun demikian, perlu diperhatikan pula bahwa menurut Lee (1966), mobilitas modal manusia dalam konsep migrasi tidak lepas dari faktor-faktor yang dimiliki oleh masing-masing negara. Faktor-faktor yang dimiliki oleh masingmasing negara tersebut tidak hanya terbatas pada kebijakan pajak. Kleven et al. (2020), mengungkapkan bahwa kekuatan respon mobilitas modal manusia tidak hanya bergantung pada yurisdiksi pajak, tetapi juga dapat dipengaruhi oleh faktor-faktor lain, seperti fasilitas lokal/nasional, ketersediaan barang/jasa publik, serta good governance negara tersebut. Kartika et al. (2020) juga mengungkapkan bahwa dalam the Global
Competitiveness Report 2017-2018 oleh World Economic Forum (WEF), terdapat lima hal utama yang mempengaruhi seseorang dalam menentukan negara tujuan investasi. Kelima hal tersebut adalah korupsi, birokrasi yang berbelit, akses terhadap keuangan, infrastruktur, konsistensi kebijakan, dan stabilitas politik.

Perbandingan faktor-faktor diluar kebijakan pajak tersebut, dapat ditunjukkan dalam Tabel 6 berikut.

Tabel 6 Persentase Good Governance di Negaranegara ASEAN Tahun 2018

\begin{tabular}{|l|c|c|c|c|c|c|c|}
\hline \multicolumn{1}{|c|}{ Negara } & $\begin{array}{c}\text { Pengend } \\
\text { alian } \\
\text { korupsi }\end{array}$ & $\begin{array}{c}\text { Efektivi } \\
\text { tas } \\
\text { pemeri } \\
\text { ntah }\end{array}$ & $\begin{array}{c}\text { Stabilit } \\
\text { as } \\
\text { politik }\end{array}$ & $\begin{array}{c}\text { Kualitas } \\
\text { peratur } \\
\text { an }\end{array}$ & $\begin{array}{c}\text { Suprem } \\
\text { asi } \\
\text { hukum }\end{array}$ & $\begin{array}{c}\text { Tingkat } \\
\text { suara } \\
\text { dan } \\
\text { akunta } \\
\text { bilitas }\end{array}$ & $\begin{array}{c}\text { Rata- } \\
\text { rata }\end{array}$ \\
\hline Singapura & 99,0 & 100 & 98,6 & 99,5 & 97,1 & 41,9 & 89,4 \\
\hline Brunei & 79,8 & 87,0 & 91,9 & 74,5 & 75,0 & 24,6 & 72,1 \\
\hline Malaysia & 63,9 & 81,3 & 54,3 & 74,0 & 74,5 & 41,4 & 64,9 \\
\hline Indonesia & 46,2 & 59,1 & 27,6 & 51,0 & 42,8 & 52,2 & 46,5 \\
\hline Thailand & 40,9 & 66,8 & 19,5 & 59,6 & 54,8 & 20,2 & 43,6 \\
\hline Vietnam & 38,0 & 53,4 & 53,8 & 36,5 & 54,3 & 9,4 & 40,9 \\
\hline Filipina & 34,1 & 55,3 & 12,9 & 56,7 & 34,1 & 47,8 & 40,2 \\
\hline Kamboja & 8,7 & 32,2 & 51,4 & 32,7 & 11,1 & 13,8 & 25,0 \\
\hline Laos & 15,4 & 24,5 & 60,0 & 20,7 & 18,8 & 4,4 & 24,0 \\
\hline Myanmar & 30,3 & 12,5 & 10,5 & 22,6 & 15,4 & 23,6 & 19,1 \\
\hline
\end{tabular}

Sumber: World Bank (2020 dalam VEPR et al., 2020)

Catatan : World Bank memberikan skor kepada setiap negara untuk setiap aspek pemerintahan (0 = sangat buruk, 100 = sangat baik) dan tidak memberi peringkat negara-negara dalam indeks keseluruhan tata kelola yang baik. Tabel ini diurutkan berdasarkan skor rata-rata sederhana.

Berdasarkan Tabel 6, terlihat bahwa ratarata persentase good governance Indonesia memiliki nilai yang cukup baik dan berada dalam 5 peringkat teratas di kawasan ASEAN. Hal ini menunjukkan bahwa Indonesia masih memiliki kapabilitas untuk bersaing dengan negara-negara lain, khususnya Malaysia dan Thailand, sehingga tetap berpotensi untuk dapat menarik lebih banyak migran internasional.

Sementara itu, dalam laporan kemudahan berbisnis (ease of doing business) 2020 dari World Bank Group (2021), Indonesia berada pada peringkat 73, sedangkan Malaysia dan Thailand memiliki peringkat yang jauh lebih tinggi. Malaysia berada di peringkat 12 dan Thailand berada di peringkat 21. Perbandingan nilai Indonesia, Malaysia dan Thailand disajikan dalam Tabel 7 berikut. 


\begin{tabular}{|c|c|c|c|c|c|}
\hline \multicolumn{6}{|c|}{$\begin{array}{c}\text { Tabel } 7 \text { Perbandingan Indikator Ease of Doing } \\
\text { Business }\end{array}$} \\
\hline \multirow{2}{*}{ Deskripsi } & \multicolumn{3}{|c|}{ Nilai } & \multicolumn{2}{|c|}{ Selisih } \\
\hline & $\begin{array}{l}\text { Indo- } \\
\text { nesia }\end{array}$ & $\begin{array}{l}\text { Malay- } \\
\text { sia }\end{array}$ & $\begin{array}{l}\text { Thaila } \\
\text { nd }\end{array}$ & $\begin{array}{l}\text { Indonesia } \\
\text {-Malaysia }\end{array}$ & $\begin{array}{l}\text { Indonesia } \\
\text {-Thailand }\end{array}$ \\
\hline $\begin{array}{l}\text { Proses } \\
\text { memulai } \\
\text { bisnis }\end{array}$ & 81,2 & 83,3 & 92,4 & $2,6 \%$ & $13,8 \%$ \\
\hline $\begin{array}{l}\text { Pengurusan } \\
\text { izin } \\
\text { konstruksi }\end{array}$ & 66,8 & 89,0 & 77,3 & $33,2 \%$ & $15,7 \%$ \\
\hline $\begin{array}{l}\text { Perolehan } \\
\text { fasilitas dan } \\
\text { keandalan } \\
\text { pasokan } \\
\text { listrik }\end{array}$ & 87,3 & 99,3 & 98,7 & $13,7 \%$ & $13,1 \%$ \\
\hline $\begin{array}{l}\text { Pendaftaran } \\
\text { properti }\end{array}$ & 60,0 & 78,9 & 69,5 & $31,5 \%$ & $15,8 \%$ \\
\hline $\begin{array}{l}\text { Perolehan } \\
\text { kredit }\end{array}$ & 70,0 & 75,0 & 70,0 & $7,1 \%$ & $0,0 \%$ \\
\hline $\begin{array}{l}\text { Perlindungan } \\
\text { terhadap } \\
\text { investor } \\
\text { minoritas }\end{array}$ & 70,0 & 88,0 & 86,0 & $25,7 \%$ & $22,9 \%$ \\
\hline $\begin{array}{l}\text { Pembayaran } \\
\text { pajak }\end{array}$ & 75,8 & 76,0 & 77,7 & $0,3 \%$ & $2,5 \%$ \\
\hline $\begin{array}{l}\text { Perdagangan } \\
\text { lintas batas }\end{array}$ & 67,5 & 88,5 & 84,6 & $31,1 \%$ & $25,3 \%$ \\
\hline $\begin{array}{l}\text { Penegakan } \\
\text { kontrak dan } \\
\text { kualitas } \\
\text { proses } \\
\text { peradilan }\end{array}$ & 49,1 & 68,2 & 67,9 & $38,9 \%$ & $38,3 \%$ \\
\hline $\begin{array}{l}\text { Pemulihan } \\
\text { kebangkrutan }\end{array}$ & 68,1 & 67,0 & 76,8 & $-1,6 \%$ & $12,8 \%$ \\
\hline
\end{tabular}

Sumber: Diolah dari World Bank Group (2021a, 2021b, 2021c)

Berdasarkan Tabel 7, terlihat bahwa meskipun peringkat umum Indonesia berada jauh di bawah Malaysia dan Thailand, nilai Indonesia dalam aspek pembayaran pajak tidak memiliki perbedaan yang signifikan dengan Malaysia dan Thailand. Dengan demikian faktor pajak dalam kemudahan berbisnis di Indonesia masih dapat bersaing dengan Malaysia dan Thailand.

Sementara itu, perbedaan yang cukup signifikan antara Indonesia, Malaysia dan Thailand terdapat pada aspek proses memulai bisnis, pengurusan izin konstruksi, pendaftaran properti, perlindungan terhadap investor minoritas, perdagangan lintas batas, serta penegakan kontrak dan kualitas proses peradilan. Rupanya, kelemahan Indonesia dalam beberapa aspek tersebut telah menjadi agenda reformasi dalam Undang-Undang Cipta Kerja. Kementerian Koordinator Bidang Perekonomian (2020) merangkum beberapa agenda reformasi dalam Undang-Undang Cipta Kerja sebagai berikut.

1. Pemerintah melakukan penyederhanaan perizinan berusaha melalui pengintegrasian 700 pasal dari 52 undang-undang.
2. Pemerintah menyederhanakan persyaratan investasi, contohnya dengan menetapkan priority list atas bidang usaha yang didorong untuk investasi, dan pemberian kesempatan kepada kegiatan usaha UMKM untuk bermitra dengan modal asing.

3. Pemerintah membuat proses berusaha menjadi lebih cepat dan mudah dengan melakukan percepatan proses izin berusaha.

4. Pemerintah memberikan perlindungan dan jaminan bagi pekerja dalam mendukung investasi, yang di dalamnya juga termasuk rencana penggunaan tenaga kerja asing.

5. Pemerintah memperluas peluang investasi dan mendorong kegiatan lalu lintas perdagangan internasional dengan melakukan optimalisasi kawasan ekonomi.

6. Pemerintah melakukan standardisasi administrasi pemerintahan dengan tujuan untuk mengharmonisasikan dan mensinkronisasikan berbagai regulasi.

7. Pemerintah juga berkomitmen untuk melakukan pengenaan sanksi proporsional melalui pemisahan sanksi administratif dengan sanksi pidana, pengutamaan pendekatan ultimum remedium, serta penghindaran tumpang tindih kewenangan.

Berdasarkan hal tersebut, meskipun fasilitas pajak yang termuat dalam reformasi perpajakan tidak memiliki keunggulan signifikan dibandingkan negara-negara lain, kombinasi antara reformasi perpajakan dan reformasi sektorsektor lain dalam Undang-Undang Cipta Kerja dapat dikembangkan secara produktif untuk menguatkan pengaruh yang dimiliki Indonesia. Pada akhirnya, hal tersebut akan meningkatkan daya tarik Indonesia di mata internasional dan secara tidak langsung dapat menjadi magnet bagi migran asing yang terampil untuk bermigrasi ke Indonesia.

\section{KESIMPULAN}

Pada dasarnya, Undang-Undang Cipta Kerja masih tetap menggunakan asas domisili dalam menentukan status subjek pajak sebagaimana Undang-Undang Pajak Penghasilan. Hal ini ditunjukkan dengan dipertahankannya unsur keberadaan (existence) sebagai kriteria utama dalam penentuan status subjek pajak. Namun, penjabaran kriteria subjek pajak orang pribadi yang termuat dalam Undang-Undang Cipta Kerja lebih jelas karena menyelipkan istilah-istilah kewarganegaraan dan menyantumkan tie-breaker rule. Penjabaran tersebut dapat menegaskan kembali bahwa aspek perpajakan Indonesia tidak melihat dari sisi WNI atau WNA, melainkan dengan melihat orang tersebut masuk dalam kategori 
subjek pajak dalam negeri (SPDN) atau subjek pajak luar negeri (SPLN) berdasarkan kriteriakriteria yang dimilikinya.

Selain memperjelas kriteria subjek pajak orang pribadi, Undang-Undang Cipta Kerja juga menetapkan beberapa ketentuan baru terhadap subjek pajak orang pribadi, seperti skema khusus pengenaan pajak terhadap WNA yang telah menjadi SPDN, serta penghapusan pajak penghasilan atas dividen yang berasal dari dalam negeri atau luar negeri dan penghasilan lain dari luar negeri. Meskipun ketentuan-ketentuan tersebut terlihat sebagai langkah besar yang diambil Indonesia untuk menggeser asas pengenaan pajaknya menuju territorial system, jika dilihat lebih lanjut, pemberlakuan ketentuan tersebut diikuti dengan syarat-syarat tertentu. Undang-Undang Cipta Kerja pun tidak mengubah narasi Pasal 4 Ayat (1) yang menyatakan bahwa objek pajak adalah penghasilan yang diterima atau diperoleh wajib pajak baik berasal dari Indonesia maupun dari luar Indonesia, dengan nama dan dalam bentuk apapun. Dengan demikian, asas pengenaan pajak di Indonesia dapat dikategorikan ke dalam sistem pajak hybrid yang masih memiliki kecenderungan pada worldwide system.

Perubahan ketentuan yang melingkupi subjek pajak orang pribadi tersebut juga dapat berdampak terhadap pajak penghasilan. Dampak tersebut diantaranya mengurangi potensi penerimaan pajak penghasilan atas dividen dan penghasilan lain dari luar negeri, serta mengurangi potensi penerimaan PPh Pasal 26 bruto atas penghasilan bunga obligasi (termasuk syariah) yang diterima/diperoleh WPLN selain BUT.

Penerapan skema pajak khusus dan pengecualian pajak atas beberapa penghasilan luar negeri juga dapat menimbulkan potensi perbedaan tarif pajak efektif. Namun, perlu diingat bahwa penerapan ketentuan tersebut tidak diberlakukan secara cuma-cuma, tetapi disertai dengan syarat tertentu, seperti alih pengetahuan dan investasi dalam negeri. Syarat-syarat tersebut mengindikasikan bahwa dibalik kebijakan pajak yang diberlakukan, terdapat niat pemerintah untuk meningkatkan investasi modal dan sumber daya manusia dalam negeri untuk membawa Indonesia menuju perekonomian yang lebih baik. Hal tersebut masih sesuai dengan tujuan utama pemungutan pajak, yakni demi sebesar-besarnya kemakmuran rakyat.

Terlepas dari berbagai potensi dampak tersebut, rupanya pemberlakuan skema khusus tidak memberikan keunggulan signifikan terhadap mobilitas sumber daya manusia dibandingkan dengan negara-negara lain, seperti Malaysia dan Thailand. Meskipun demikian, setelah melihat faktor-faktor lain, Indonesia memiliki persentase good governance yang cukup baik. Indonesia juga terus berusaha melakukan reformasi dalam bidang-bidang lain yang menunjang kemudahan berusaha sehingga tetap memiliki potensi untuk menarik lebih banyak migran internasional. Dengan demikian, kombinasi antara reformasi perpajakan dan reformasi sektor-sektor lain dalam Undang-Undang Cipta Kerja dapat dikembangkan secara produktif untuk meningkatkan daya tarik Indonesia di mata internasional sehingga secara tidak langsung juga dapat menjadi magnet bagi migran asing yang terampil untuk bermigrasi ke Indonesia.

\section{IMPLIKASI DAN KETERBATASAN}

Hasil penelitian ini menunjukkan bahwa pada dasarnya reformasi peraturan perpajakan terutama pajak penghasilan dalam UndangUndang Cipta Kerja bertujuan untuk meningkatkan investasi modal dan sumber daya manusia dalam negeri dalam rangka membawa Indonesia menuju perekonomian yang lebih baik. Segala dampak yang timbul hendaknya dipandang dalam perspektif yang lebih luas sesuai dengan tujuan utama pemungutan pajak, yakni demi sebesarbesarnya kemakmuran rakyat.

Meskipun demikian, tetap diperlukan pengawasan dari pemerintah agar strategi pemerintah tersebut dapat sesuai dengan harapan. Dampak hilangnya pendapatan dari pemberlakuan ketentuan-ketentuan baru dalam Undang-Undang Cipta Kerja harus seimbang dengan imbal hasil atas pemingkatan kegiatan penanaman modal dalam negeri. Dengan demikian, sejalan dengan pernyataan Saptono dan Ayudia (2021), pemerintah perlu memprioritaskan kebutuhan investasi dalam negeri dan mengawasi implementasi kebijakan tersebut agar tidak tercipta ketimpangan lebih lanjut.

Kemudian, penelitian ini juga memiliki beberapa keterbatasan, salah satunya adalah keterbatasan pustaka. Hal tersebut dikarenakan Undang-Undang Cipta Kerja tergolong kebijakan yang masih baru sehingga sumber-sumber pustaka yang membahas substansi perubahan dan dampak dari Undang-Undang Cipta Kerja tersebut masih terbatas.

\section{PENGHARGAAN (ACKNOWLEDGEMENT)}

Penulis menyadari bahwa penyelesaian karya tulis ini tidak lepas dari peran serta berbagai pihak. Oleh karena itu, penulis mengucapkan terima kasih kepada para dosen Politeknik Keuangan Negara STAN yang telah memberikan bimbingan, dukungan, dan motivasi sehingga karya 
tulis ini dapat terselesaikan. Penulis juga menyadari bahwa karya tulis ini masih jauh dari kesempurnaan. Dengan demikian, penulis bertanggung jawab penuh atas segala kesalahan dan kealpaan yang ada.

\section{DAFTAR PUSTAKA (REFERENCES)}

Asian Development Bank. (2019). Skilled Labor Mobility and Migration. Edward Elgar Publishing. https://doi.org/10.4337/9781788116176

Badan Pusat Statistik. (2019). Analisis Mobilitas Tenaga Kerja Hasil Survei Angkatan Kerja Nasional 2018. Badan Pusat Statistik.

Claus, E., Claus, I., \& Dorsam, M. (2011). Effects of Taxation on Migration: Some Evidence for the ASEAN and APEC Economies. Asian Development Review, 28(1), 22-50. https://doi.org/10.2139/ssrn.1729023

Darussalam, Kristiaji, B. B., \& Dhora, K. A. (2018). Sistem Pemajakan: Dari Worldwide ke Territorial, Bagaimana dengan Indonesia? PT Dimensi Internasional Tax.

Darussalam, Septriadi, D., Kristiaji, B. B., \& Vissaro, D. (2019). Era Baru Hubungan Otoritas Pajak dengan Wajib Pajak. PT Dimensi Internasional Tax.

Deloitte Southeast Asia Ltd. (2020). 2020 Guide to Taxation in Southeast Asia by Deloitte Chinese Services Group. https://www2.deloitte.com/id/en/pages/tax /articles/guide-to-taxation-in-sea-2020.html

Direktorat Jenderal Pajak. (n.d.). Asas Pengenaan Pajak. Diambil 15 Mei 2021, dari https://www.pajak.go.id/id/asaspengenaan-pajak

Fleming, J. C., Peroni, R. J., \& Shay, S. E. (2008). Some Perspectives from the United States on the Worldwide Taxation vs. Territorial Taxation Debate. Journal of the Australasian Tax Teachers Association, 3(2), 35-86.

Kadir, A. (2016). Kapita Selekta Perpajakan di Indonesia. In Kapita Selekta Perpajakan di Indonesia. Pustaka Bangsa Press.

Kartika, W., Hidayat, N., Ridwan, G., Lumbantoruan, M., Thaariq, R. M., \& Ramdlaningrum, H. (2020). Omnibus Law Perpajakan: Dibilang Genap, Dipagar Ganjil. Perkumpulan PRAKARSA.

Kementerian Koordinator Bidang Perekonomian. (2020). Cipta Kerja. http://dikti.kemdikbud.go.id/wpcontent/uploads/2020/10/Booklet-UUCipta-Kerja.pdf

Kleven, H. J., Landais, C., Saez, E., \& Schultz, E. (2014). Migration and Wage Effects of Taxing Top Earners: Evidence from the Foreigners'
Tax Scheme in Denmark. The Quarterly Journal of Economics, 129(1), 333-378. https://doi.org/10.1093/QJE/QJT033

Kleven, H., Landais, C., Muñoz, M., \& Stantcheva, S. (2020). Taxation and Migration: Evidence and Policy Implications. Journal of Economic Perspectives, 34(2), 119-142. https://doi.org/10.1257/JEP.34.2.119

Lee, E. S. (1966). A Theory of Migration. Demography 1966 3:1, 3(1), 47-57. https://doi.org/10.2307/2060063

Marantika, A. (2021). Dividen Bebas Pajak, Bentuk Reformasi Perpajakan dan Kontribusi Bersama Membangun Negeri. https://www.kemenkeu.go.id/publikasi/artik el-dan-opini/dividen-bebas-pajak-bentukreformasi-perpajakan-dan-kontribusibersama-membangun-negeri/

Mullins, P. J. (2006). Moving to Territoriality? Implications for the United States and the Rest of the World. IMF Working Papers, 06(161), 1. https://doi.org/10.5089/9781451864212.00 1

Undang-Undang Republik Indonesia Nomor 36 Tahun 2008 tentang Perubahan Keempat atas Undang Undang Nomor 7 Tahun 1983 Tentang Pajak Penghasilan, (2008).

Undang-Undang Nomor 16 Tahun 2009 tentang Penetapan Peraturan Pemerintah Pengganti Undang-Undang Nomor 5 Tahun 2008 Tentang Perubahan Keempat atas UndangUndang Nomor 6 Tahun 1983 Tentang Ketentuan Umum dan Tata Cara Perpajakan Menjadi Undang-Undang, (2009).

Undang-Undang Republik Indonesia Nomor 11 Tahun 2020 tentang Cipta Kerja, (2020).

Peraturan Pemerintah Republik Indonesia Nomor 9 Tahun 2021 tentang Perlakuan Perpajakan untuk Mendukung Kemudahan Berusaha, (2021).

Saptono, P. B., \& Ayudia, C. (2021). Income Tax Issues on the Omnibus Law and Its Implications in Indonesia. AKRUAL: Jurnal Akuntansi, 12(2), 164. https://doi.org/10.26740/jaj.v12n2.p164178

Setiawan, D. A. (2019). Sistem Pajak Jadi Teritorial, Begini Penjelasan Dirjen Pajak. https://news.ddtc.co.id/sistem-pajak-jaditeritorial-begini-penjelasan-dirjen-pajak17001

Setiyawan, D. (2019). Status Hukum Wajib Pajak Warga Negara Indonesia Yang Tinggal Menetap Di Luar Negeri. Jurnal HUKUM BISNIS, 3(2), 155-169. https://jurnal.narotama.ac.id/index.php/huk 
Yustika Dewi Prastiwi, Rd. Tatan Jaka Tresnajaya

umbisnis/article/view/744

Sugiyono. (2013). Metode Penelitian Kuantitatif, Kualitatif dan R\&D. Penerbit Alfabeta.

Suparnyo. (2012). Hukum pajak (SUATU SKETSA ASAS). In Pustaka Magister Semarang.

United Nations. (n.d.). International Migrant Stock 2019. Diambil 2 Mei 2021, dari https://www.un.org/en/development/desa/ population/migration/data/estimates2/esti matesgraphs.asp?2g2

VEPR, Oxfam in Vietnam, The PRAKARSA, \& TAFJA. (2020). Towards Sustainable Tax Policies in the ASEAN Region: The Case of Corporate Tax Incentives. VEPR, Oxfam in Vietnam, The PRAKARSA, \& TAFJA.

Wicaksono, M. A. (2014). Pengaruh Persepsi Sistem Perpajakan, Keadilan Pajak, Diskriminasi Pajak, dan Pemahaman Perpajakan terhadap Perilaku Penggelapan Pajak (Studi Empiris Pada Wajib Pajak Orang Pribadi Terdaftar di KPP Pratama Purworejo). Skripsi Sarjana Ekonomi, 1--57.

World Bank Group. (2021a). Economy Profile Indonesia: Doing Business 2020.

World Bank Group. (2021b). Economy Profile Malaysia: Doing Business 2020.

World Bank Group. (2021c). Economy Profile Thailand: Doing Business 2020. 